\title{
PENGARUH PIJAT OKSITOSIN TERHADAP PENURUNAN TINGGI FUNDUS UTERI PADA IBU POSTPARTUM NORMAL
}

\author{
Nurniati Tianastia Rullyni*) ; Rahmadona ; Astri Yulia Sari Lubis \\ Jurusan Kebidanan; Poltekkes Kemenkes Tanjungpinang \\ Jl. Arief Rahman Hakim No.1 ; Tanjung Ayun Sakti; Bukit Bestari; Kota Tanjungpinang
}

\begin{abstract}
Abstrak
Masih banyak kejadian perdarahan ibu postpartum dikarenakan lemah atau tidak adanya kontraksi uterus di bidan praktik mandiri Kota Tanjungpinang. Dengan tidak adanya kontraksi uterus dapat mempengaruhi tinggi fundus uteri. Penelitian ini bertujuan untuk mengetahui pengaruh pijat oksitosin terhadap penurunan tinggi fundus uteri pada ibu postpartum normal. Desain penelitian ini adalah eksperimen posttest only control group dengan jumlah sampel 40 orang ibu postpartum. Sampel di hitung menggunakan rumus uji hipotesis terhadap rerata dua populasi independen dengan teknik sampling randomisasi blok. Perlakuan dilakukan dengan pijat oksitosin selama 2-3 menit setiap hari, dilaksanakan selama lima hari postpartum. Data yang diperoleh dianalisis menggunakan uji Independent sampel $t$-test dengan mengendalikan usia, paritas, dan inisiasi menyusui dini. Hasil penelitian menunjukan ada pengaruh pijat oksitosin terhadap penurunan tinggi fundus uteri pada ibu postpartum normal.
\end{abstract}

Kata kunci: pijat oksitosin ; tinggi fundus uteri ; postpartum normal

\begin{abstract}
There are so many case about maternal postpartum hemorrage due to weak or absence of uterine contraction at independent practice midwife in Tanjung pinang. With the absence of uterine contraction can affect high of fundus uterine. The purpose of research to find out ocytocyn massage affect againts decreased high of fundus uterine for normal maternal pospartum. The research of design is pottest only control group experiment with total sampel 40 postpartum maternal. The sample is calculated using the hypothesis test formula on the average of two independent populations with the block randomization sampling technique. Oxytocin massage treatment for 2-3 minutes in five days pospartum. Obtained data were analyzed use independent sample $t$-test by controlling the age, parity and early initiation breastfeeding. The research of result show there is oxytocin massage affect againts decreased high of fundus uterine for normal postpartum maternal.
\end{abstract}

Keywords: oxytocin massage; high of fundus uterine ; normal postpartum

\section{Pendahuluan}

Tinggi rendahnya angka kematian ibu (AKI) dapat dipakai untuk mengukur taraf program kesehatan di suatu negara khususnya program kesehatan ibu dan anak. Berdasarkan Survey
Demografi Kesehatan Indonesia (SDKI) tahun 2012, AKI di Indonesia mengalami kenaikan sebesar 359 per 100.000 kelahiran hidup, dibandingkan rata-rata kematian ibu berdasarkan SDKI 2007 yang berjumlah 228 per 100.000 kelahiran hidup dengan penyebab langsung $50 \%$ kematian ibu pada masa nifas terjadi dalam 24 jam pertama yang sebagian 
besar disebabkan oleh karena perdarahan postpartum (Badan Pusat Statistik, BKKBN, Kementerian Kesehatan, 2007; Departemen Kesehatan, 2010; Kementerian Kesehatan Republik Indonesia, 2011). AKI di Kota Tanjungpinang pada tahun 2014 sebesar 217,64/100.000 kelahiran hidup dengan jumlah ibu meninggal sebanyak 11 orang (Dinas Kesehatan Provinsi Kepulauan Riau, 2013; Dinas Kesehatan Kota Tanjungpinang, 2015). Penyebab terbanyak dari perdarahan setelah persalinan $50 \%-60 \%$ karena kelemahan atau tidak adanya kontraksi uterus (Saifuddin AB, 2009; Mochtar R, 2010).

Stanton CK, Samuel N, dan Luke CM (2013) menyatakan upaya penanganan perdarahan postpartum adalah dengan pemberian oksitosin, dimana oksitosin mempunyai peranan penting dalam merangsang kontraksi otot polos uterus sehingga uterus dapat berkontraksi dengan baik (Stanton CK, Samuel N, Luke CM, 2013). Uterus yang berkontraksi baik secara bertahap akan berkurang tinggi dan ukurannya sampai tidak bisa diraba lagi di atas simfisis pubis. Proses ini dikenal dengan involusi uterus (Fraser MD \& Cooper M).

Upaya mempertahankan kontraksi dan retraksi serat miometrium yang kuat dari tempat pelepasan plasenta dapat dilakukan dengan merangsang pengeluaran oksitosin alamiah dengan melakukan pijatan yang dikenal dengan pijat oksitosin. Pijat oksitosin adalah suatu tindakan pemijatan di sepanjang tulang belakang mulai dari nervus 5-6 hingga scapula yang akan mempercepat kerja saraf parasimpatis untuk menyampaikan perintah ke bagian posterior otak sehingga oksitosin bisa keluar (Biancuzzo, M , 2003; Roesli U, 2008; Hamrarani ST, 2010;). Oksitosin dapat mempertahankan kontraksi uterus, mempercepat dan mengendalikan perdarahan sehingga menjadi bagian penting dari perawatan postpartum (Bobak IM dkk, 2004).

Pijat oksitosin sebagai upaya preventif yang merupakan pengobatan komplementer-alternatif yang berlandaskan ilmu pengetahuan biomedik melalui intervensi tubuh dan pikiran sesuai yang dinyatakan dalam Permenkes nomor 1109 tahun 2007 tentang Penyelenggaraan Pengobatan Komplementer Alternatif di Fasilitas Kesehatan. Pijat oksitoksin merupakan salah satu bentuk asuhan kebidanan yang dapat dilakukan pada ibu postpartum (Menkes RI, 2007).

Menurut studi pendahuluan yang dilakukan di bidan praktik mandiri (BPM) kota
Tanjungpinang pada bulan Maret 2015, menunjukkan bahwa pijat oksitosin belum pernah diterapkan dalam asuhan pada ibu-ibu postpartum normal namun hanya sebatas tindakan farmakologik dalam bentuk pemberian oksitoksin sintetis pada manajemen aktif kala III dan ditemukan banyaknya kejadian uterus gagal berkontraksi pada ibu postpartum yang menyebabkan terhentinya proses involusi uterus, sehingga terdapat variasi terhadap penurunan tinggi fundus uteri pada ibu postpartum. Penelitian ini dilakukan untuk mengetahui pengaruh pijat oksitosin terhadap penurunan tinggi fundus uteri pada ibu postpartum normal.

\section{Metode}

Desain pada penelitian ini eksperimen, posttest only control group design. Penelitian dilakukan di BPM Kota Tanjungpinang. Penelitian dilakukan mulai bulan Maret s/d Agustus tahun 2015. Populasi penelitian diestimasikan sejumlah 5859 orang ibu postpartum normal yang melahirkan di BPM kota Tanjungpinang. ${ }^{15}$ Sampel penelitian sejumlah 40 ibu postpartum (masing-masing kelompok 20 orang) yang di hitung menggunakan rumus uji hipotesis terhadap rerata dua populasi independen. Dengan teknik sampling randomisasi blok. Variabel independen adalah pijat oksitosin yang dilakukan pada ibu postpartum yang dilakukan selama 2-3 menit dilakukan setiap hari dari hari ke-1 sampai hari ke-5. Variabel dependen adalah tinggi fundus uteri yang diukur rata-rata penurunan tinggi fundus uteri ibu postpartum setelah 3 kali pengukuran pada hari ke-1, hari ke-3 dan hari ke-5. Cara mengukur pijat oksitosin dengan cara menggunakan lembar observasi sesuai standar prosedur pemijatan oksitosin menurut Depkes (2005). ${ }^{17}$ Cara mengukur tinggi fundus uteri dengan mengukur dari pinggir atas simfisis ke bagian atas fundus uteri dengan pita centimeter (Bobak IM dkk, 2004). Data yang ukur adalah penurunan tinggi fundus uteri yang dianalisis menggunakan "Independen-Sample T-Test" dengan derajat kepercayaan $95 \%$.

\section{Hasil dan Pembahasan}

\section{Hasil}

Karakteristik responden berdasarkan usia, paritas, 


\section{dan inisiasi menyusu dini}

Karakteristik responden pada kedua kelompok secara statistik tidak menunjukkan perbedaan bermakna. Namun, secara deskriptif didapatkan rata-rata usia dan paritas responden lebih tinggi pada kelompok kontrol, serta kedua kelompok melaksanakan inisiasi menyusu dini. Selengkapnya lihat Tabel 1.

Tabel 1. Gambaran karakteristik responden pada kelompok intervensi dan kelompok kontrol

\begin{tabular}{lccc}
\hline Karakteristik & Intervensi $(\mathrm{n}=20)$ & $\begin{array}{c}\text { Kontrol } \\
(\mathrm{n}=20)\end{array}$ & $p_{\text {value }}{ }^{*}$ \\
\cline { 2 - 3 } & Rata-rata \pm SD & $\begin{array}{c}\text { Rata-rata } \pm \\
\text { SD }\end{array}$ \\
\hline Usia & $28,90 \pm 4,98$ & $30,70 \pm 4,25$ & $0,214^{*}$ \\
Paritas & $1,90 \pm 1,02$ & $2,55 \pm 1,19$ & $0,072^{*}$ \\
IMD & $50 \%$ & $50 \%$ & \\
\hline${ }^{*}$ p value $<0,05$ & & &
\end{tabular}

\section{Tinggi fundus uteri ibu postpartum normal}

Hasil menunjukkan rata-rata 3 kali pengukuran tinggi fundus uteri, penurunan terjadi lebih banyak pada kelompok intervensi dari kelompok kontrol, dengan mengendalikan usia, paritas, dan inisiasi menyusu dini. Setelah dilakukan uji statistik ternyata hasilnya bermakna, artinya ada pengaruh pijat oksitosin terhadap penurunan tinggi fundus uteri pada ibu postpartum normal. Selengkapnya lihat Tabel 2.

Tabel 2. Rata-rata Tinggi Fundus Uteri 3 kali pengukuran pada ibu PostPartum pada

Kelompok Intervensi dan Kelompok Kontrol

\begin{tabular}{|c|c|c|c|c|}
\hline \multirow{2}{*}{ Kelompok } & \multicolumn{3}{|c|}{ TFU 3 kali pengukuran } & \multirow{2}{*}{$p^{\text {value* }^{*}}$} \\
\hline & Mean & $S D$ & $S E$ & \\
\hline Intervensi & 9,03 & 0,67 & 0,15 & \multirow{2}{*}{0,000} \\
\hline Kontrol & 9,89 & 0,58 & 0,13 & \\
\hline
\end{tabular}

\section{Pembahasan}

Berdasarkan hasil pengukuran rata-rata tinggi fundus uteri 3 kali pengukuran pada kelompok intervensi maupun pada kelompok kontrol tidak jauh berbeda. Namun, berdasarkan hasil uji statistik pada 3 kali pengukuran tinggi fundus uteri didapatkan ada pengaruh pijat oksitosin terhadap rata-rata penurunan TFU.

Rata-rata tinggi fundus uteri antara kelompok intervensi dan kelompok kontrol sama-sama terjadi penurunan. Hal ini sesuai dengan teori Varney H, Kriebs M, Gegor C, (2008) dan Bobak IM, (2004), dimana segera setelah pengeluaran plasenta terjadi kontraksi uterus, sehingga ukuran masing-masing sel menurun secara bermakna, yaitu 50-90 $\mu \mathrm{m}$ kali 2,5-5 $\mu \mathrm{m}$ masa postpartum. Segera setelah pengeluaran plasenta tinggi fundus uteri menjadi 2 jari di bawah pusat, pada hari ke-5 postpartum uterus kurang lebih setinggi $7 \mathrm{~cm}$ atas simfisis atau setengah simfisis pusat. Terjadinya perubahan miometrium yang bersifat proteolisis, reorganisasi dan eksofiliasi tempat perlengketan plasenta yang ditandai dengan penurunan ukuran dan berat uterus (Bobak IM, dkk, 2004 ; Varney H, Kriebs M, Gegor C, 2008).

Setelah melahirkan, uterus akan kembali kekeadaan sebelum hamil yang disebut dengan involusi. Proses ini ditandai segera setelah plasenta keluar akibat kontraksi otot polos uterus (Bobak IM, dkk, 2004 ; Varney H, Kriebs M, Gegor C, 2008). Pada periode postpartum, penurunan kadar hormon estrogen dan progesteron menyebabkan terjadinya autolisis, yaitu perusakan secara langsung jaringan hipertropi yang berlebihan. Perubahan lain yang terjadi pada uterus adalah intensitas kontraksi uterus meningkat secara bermakna segera setelah bayi lahir, diduga terjadi sebagai respon terhadap penurunan volume intrauterin. Hormon oksitosin yang dilepas dari kelenjer hipofisis memperkuat dan mengatur kontraksi uterus, mengompresi pembuluh darah dan membantu haemostasis (Bobak IM, dkk, 2004 ; Morhenn V, Laura E, Beavin MA, 2012).

Hasil penelitian sesuai dengan penelitian Stanton CK (2013) yang menyatakan oksitosin mempunyai peranan penting dalam merangsang kontraksi otot polos uterus. Hormon oksitosin dapat dihasilkan melalui rangsangan pemijatan oksitosin (Stanton CK, Samuel N, Luke CM, 2013). Penelitian Morhenn V, Laura E, Beavin MA (2012) menjelaskan adanya hubungan pemijatan otot tulang belakang dengan peningkatan kadar oksitosin dan menurunkan kadar adrenocorticotropin hormone (ACTH), nitric oxide (NO) dan beta-endorphin (BE). Perbandingan efek pemijatan pada kelompok intervensi dan kelompok kontrol mempunyai perbedaan yang signifikan (Morhenn V, Laura E, Beavin MA, 2012).

Hasil penelitian Young HL, Bit RP, Sung HK (2011) dengan pemijatan dapat meningkatkan respon dalam sistem saraf otonom dengan mengaktifkan reseptor sensorik, sehingga berpengaruh dalam menghasilkan oksitosin (Young HL, Bit RP, Sung HK, 2011). Oksitosin berbentuk asam amino peptida 
sembilan yang disintesis pada syaraf hipotalamus dan dialirkan ke akson dari pituitary posterior untuk disekresikan ke dalam darah. Oksitosin juga disekresikan ke dalam otak dan dari beberapa jaringan. Hormon oksitosin yang dihasilkan bekerja pada otot polos uterus, sehingga menyebabkan uterus berkontraksi, dengan berkontraksinya uterus akan membantu proses involusi uterus yang dapat dinilai melalui tinggi fundus uteri (Stanton CK, Samuel N, Luke CM, 2013).

Penurunan rata-rata tinggi fundus uteri pada kelompok intervensi lebih turun dari pada kelompok konrol. Hal ini membuktikan teori bahwa pelaksanaan pijat oksitosin pada ibu postpartum dapat membantu mempercepat proses involusi uteri yang salah satunya dapat dinilai melalui pengukuran terhadap tinggi fundus uteri ibu postpartum (Departemen Kesehatan Republik Indonesia, 2005).

Kontraksi pada uterus akan mempercepat proses involusi uterus, yaitu perubahan retrogresif pada uterus yang menyebabkan berkurangnya ukuran uterus. Uterus yang berkontraksi dengan baik secara bertahap akan berkurang ukurannya, sampai tidak dapat dipalpasi lagi di atas simfisis pubis (Varney $\mathrm{H}$, Kriebs M, Gegor C, 2008).

Dalam penelitian ini hanya dilihat involusi uterus berdasarkan tinggi fundus uteri tanpa memandang involusi dari aspek lainnya yang didapatkan hasil untuk kedua kelompok terdapat perbedaan yang signifikan terhadap rata-rata penurunan tinggi fundus uteri. Namun tidak dapat diketahui secara pasti pada hari postpartum keberapa proses involusi uteri selesai terjadi sampai tinggi fundus uteri tidak teraba lagi di atas simfisis pubis dikarenakan hanya menilai tinggi fundus uteri sampai hari ke-5 saja.

Menurut teori, involusi uteri dapat diamati dari luar yaitu dengan memeriksa fundus uteri dengan cara segera setelah persalinan, tinggi fundus uteri $2 \mathrm{~cm}$ dibawah pusat dan 12 jam kemudian kembali $1 \mathrm{~cm}$ diatas pusat dan menurun kira-kira $1 \mathrm{~cm}$ setiap hari; pada hari kedua setelah persalinan tinggi fundus uteri 1 $\mathrm{cm}$ di bawah pusat, pada hari ke 3-4 tinggi fundus uteri $2 \mathrm{~cm}$ di bawah pusat. Pada hari ke 5-7 tinggi fundus uteri setengah pusat simpisis. Pada hari ke-10 tinggi fundus tidak teraba (Bobak IM, dkk, 2004; Young HL, Bit RP, Sung HK, 2011).

Oksitosin merupakan suatu hormon yang disekresikan oleh neurohipofisis yang secara khusus menyebabkan kontraksi uterus
(Stanton CK, Samuel N, Luke CM, 2013). Oksitosin menginduksi otot polos miometrium uteri pada persalinan. Pemicu sintesis reseptor oksitosin dapat berupa peningkatan rasio estrogen terhadap progesteron seiring berkurangnya konsetrasi hormon progesteron selama persalinan. Oksitosin dilepaskan dari hipofisis posterior selama persalinan akibat rangsangan dilatasi serviks yang mengirimkan serat aferen ke sistem saraf pusat sehingga menyebabkan kelenjer hipofisis posterior meningkatkan sekresi oksitosinnya (Greenstein B, Diana W, 2010).

Hormon oksitosin akan memicu kontraksi otot polos pada uterus sehingga akan terjadi involusi uterus dan mencegah terjadinya perdarahan. Oksitosin merupakan suatu hormon yang dapat memperbanyak masuknya ion kalsium kedalam intrasel. Keluarnya hormon oksitosin akan memperkuat ikatan aktin dan myosin sehingga kon traksi uterus semakin kuat dan proses involusi uterus semakin bagus (Bobak IM, dkk, 2004).

Penelitian Young HL (2011) menjelaskan adanya hubungan pemijatan yang dilakukan di daerah veretebralis L4 sampai S1 terhadap sistem saraf otonom sehingga HRV, serum kortisol dan tingkat neuroepinefrin akan diturunkan dan meningkatkan kadar oksitosin. Dengan adanya pemijatan oksitosin, terjadi rangsangan di korda spinalis yang mana berfungsi sebagai penghubung saraf antara otak dan sistem saraf perifer. Semua komunikasi ke atas dan ke bawah korda spinalis terletak di jaras-jaras (traktus) asendens yang menyalurkan sinyal dari masukan aferen ke otak. Substansia grisea yang terletak di tengah korda spinalis mengandung antarneuron-antarneuron yang terletak antara masukan aferen dan keluaran eferen serta badan sel neuron eferen. Serat aferen dan eferen yang masing-masing membawa sinyal ke dan dari korda spinalis, menyatu menjadi saraf spinalis. Saraf-saraf ini melekat ke korda spinalis berpasangan di sepanjang korda. Neuron inhibitorik dan neuron kolimergik eksitatorik membuat kontak sinaps dengan neuron oksitosin neurosekretorik di nucleus paraventrikularis dan supraoptikus. Kemudian hipotalamus memproduksi hormon oksitosin dan dialirkan menuju hipofisis posterior, oksitosin menuju ke uterus maka mioendometrium akan mengalami kontraksi sehingga merangsang terjadinya kontraksi (Young HL, Bit RP, Sung HK, 2011; Greenstein B, Diana W, 2010). 
Jadi, kadar oksitosin akan meningkat jika ibu dalam keadaan rileks, dengan pemijatan, kondisi rileks akan tercipta, sehingga produksi oksitosin dapat meningkat dan dapat memaksimalkan kontraksi uterus yang dapat membantu proses involusi uterus. Penelitian ini melakukan pemijatan pada otot tulang belakang yang bertujuan agar ibu merasa rileks dan nyaman sehingga akan mempengaruhi peningkatan kadar hormon oksitosin sehingga kontraksi uterus menjadi baik dan membantu proses involusi uterus pada masa postpartum. Namun, dalam penelitian ini tidak mempertimbangkan keadaan lingkungan, seperti keadaan dan kenyamanan ruangan serta pendamping persalinan, dimana dengan lingkungan dan ruangan yang nyaman serta adanya pendamping persalinan merupakan faktor yang mempengaruhi peningkatan kadar hormon oksitosin.

\section{Simpulan dan Saran}

Ada pengaruh pijat oksitosin terhadap penurunan tinggi fundus uteri pada ibu postpartum normal. Sebagai bahan masukan bagi bidan praktik mandiri yang belum menerapkan pijat oksitosin untuk menjadikan pijat oksitosin ini sebagai asuhan kebidanan intervensi non farmakologi dan prosedur tetap asuhan kebidanan pada ibu postpartum.

\section{Ucapan Terima Kasih}

Terima kasih disampaikan kepada Poltekkes Kemenkes Tanjungpinang yang telah mendanai keberlangsungan penelitian ini, juga disampaikan kepada pihak-pihak yang telah membantu pelaksanaan penelitian.

\section{Daftar Pustaka}

Badan Pusat Statistik, BKKBN, Kementerian Kesehatan. 2007. Survei demografi kesehatan Indonesia Tahun 2007. Pelayanan kesehatan ibu dan anak.

Departemen Kesehatan. Riset Kesehatan Dasar (Riskesdas). 2010. Badan Penelitian dan Pengembangan Kesehatan.

Kementerian Kesehatan Republik Indonesia. 2011. Pusat data dan informasi. Jakarta: Kemenkes RI.

Dinas Kesehatan Provinsi Kepulauan Riau. 2013. Data kesehatan keluarga Provinsi Kepulauan Riau.

Dinas Kesehatan Kota Tanjungpinang. 2015.
Data Kesehatan Keluarga Kota

Tanjungpinang.

Saifuddin, AB. 2009. Perdarahan setelah bayi lahir, buku acuan nasional pelayanan kesehatan maternal dan neonatal. Jakarta: YBP-SP;

Mochtar, R. 2010. Sinopsis Obstetri. Jakarta: EGC.

Stanton CK., Samuel N, Luke CM. Effect on postpartum haemorrahage of prophylactic oxytocin (10 IU) by injection by community health officer in Ghana: a community-based, cluster-randomized trial. Australia: The University of Adelide. Journal.pmed: October 2013 [cited 2013 Oct 1]; 10 (10) e100524: [about 14 p]. Available from: http:/ / www .ncbi.nlm.nih.gov/pmc/articl es/PMC3794862/

Fraser, MD \& Cooper, M. 2004. Myles textbook for midwives. 14th. ed Elsevier Publisher;

Biancuzzo, M. 2003. Breastfeeding the newborn: clinical strategies for nurses. 2nd ed. St. Louis: Mosby.

Roesli, U. 2008. Inisiasi menyususi dini plus ASI ekslusif. Jakarta: Pustaka Bunda.

Hamrarani, ST. 2010. Pengaruh pemijatan oksitosin terhadap involusi uterus pada ibu postpartum yang mengalami persalinan lama di rumah sakit wilayah kabupaten klaten. Jakarta: Universitas Indonesia. Tesis Universitas Indonesia, Fakultas Ilmu Kedokteran.

Bobak IM, Lowdermilk D, Jensen M, Perry S. 2004. Buku ajar keperawatan maternitas. Jakarta: EGC;

Peraturan menteri kesehatan republik indonesia nomor 1109 tahun 2007 tentang penyelenggaraan pengobatan komplementer alternatif di fasilitas kesehatan, Bab. VII, pasal. 21: tentang surat tugas/surat ijin kerja tenaga pengobatan komplementer alternatif. Jakarta: Menkes RI, 2007.

Dinas Kesehatan Kota Tanjungpinang. 2014. Data Kesehatan Keluarga Kota Tanjungpinang.

Sastroasmoro, S. 2011. Dasar-dasar metodologi penelitian klinis. Jakarta: Sagung Seto;

Departemen Kesehatan Republik Indonesia. 2005. Standar pelayanan kebidanan. Jakarta: Depkes RI.

Varney H, Kriebs M, Gegor C. 2008. Buku ajar asuhan kebidanan. Volume 2. Jakarta: EGC. 
Cunningham FG, Leveno K, Bloom SL, Hauth C, Rause D, Spong CY. 2012. Obstetri williams. Jakarta: EGC.

Morhenn V, Laura E, Beavin MA. Massage increase oxytocin and reduces adrenocorticotropin hormone in humans. San Diego: University of California San Diego Medical Center. J.Alternative Therapies. Nov-Dec 2012; 18 (6): [about 4 p]. Available from: http://www.ncbi.nlm.nih.gov/pubmed/2 3251939

Young HL, Bit RP, Sung HK. The effects of heat and massage application on autonomic nervous system. Korea: Department of Rehabilitation Medicine, Wonju Christian Hospital, Yonsei University Wonju College of Medicine. Yonsei Med J; Nov 2011 [cited 2011 Nov 1]; 52 (6): [about 8 p]. Available from: http://www.ncbi.nlm.nih.gov/pmc/articl es/PMC3220246/

Ambarwati. 2008. Asuhan kebidanan nifas. Yogyakarta: Mitra Cendekia.

Greenstein B, Diana W. 2010. Hormon oksitosin, alih bahasa at a glance sistem endokrin. edisi kedua. Jakarta: Erlangga. 